\title{
Dermoscopic and Histopathological Findings in Osteoma Cutis Involving the Face and Scalp
}

\author{
Marina Romero Navarrete ${ }^{1}$, María-Elisa Vega Memije ${ }^{2}$, Roberto Arenas Guzmán”, \\ Aureliano Castillo Solana ${ }^{4}$, Gloria E. Reyes López ${ }^{5}$, Julieta Ruiz Esmenjaud ${ }^{6}$
}

\begin{abstract}
1 Dermatology, Hospital General de Acapulco, Secretaría de Salud, Guerrero, Mexico 2 Dermatopathology, Hospital General Dr. Manuel Gea González, Ciudad de Mexico, Mexico 3 Mycology, Hospital General Dr. Manuel Gea González, Ciudad de Mexico, Mexico 4 Epidemiology, Hospital General de Acapulco, Secretaría de Salud, Guerrero, Mexico 5 Otorhinolaryngology, Hospital General de Acapulco, Secretaría de Salud, Guerrero, Mexico 6 Dermatology, Private Practice, Ciudad de México, Mexico
\end{abstract}

Key words: plaque-like osteoma cutis, primary osteoma cutis, secondary osteoma cutis

Citation: Romero Navarrete M, Vega Memije M-E, Arenas Guzmán R, Castillo Solana A, Reyes López GE, Ruiz Esmenjaud J. Dermoscopic and histopathological findings in osteoma cutis involving the face and scalp. Dermatol Pract Concept. 2019;9(1):24-27. DOI: https://doi. org/10.5826/dpc.0901a07

Published: January 31, 2019

Copyright: @2019 Romero Navarrete et al. This is an open-access article distributed under the terms of the Creative Commons Attribution License, which permits unrestricted use, distribution, and reproduction in any medium, provided the original author and source are credited.

Funding: None.

Competing interests: The authors have no conflicts of interest to disclose.

Authorship statement: All authors have contributed significantly to this publication.

Corresponding author: Marina Romero Navarrete, De la Nao 1809-501 Fraccionamiento La Bocana, Acapulco, Guerrero, México, 39670. Email: marinaromero@live.com.mx

\section{Introduction}

Osteoma cutis is a benign uncommon tumor characterized by the presence of bone tissue in dermis or hypodermis. It is classified as primary when the bone tissue originates from the skin without a preexisting lesion and secondary when there has been a previous inflammatory, traumatic, cicatricial, or neoplastic process [1]. We report a case of primary plaque osteoma cutis.

\section{Case Presentation}

A 27-year-old woman presented with a 9-year history of slowly enlarging, hard lesions on her scalp, forehead, and nose, which created 2 irregular plaques that were painful on palpation, both with erythema in their periphery. The plaques measured approximately 1 to $5 \mathrm{~mm}$ in diameter (Figure 1).
Dermoscopy showed concentric white and yellowish structures with an erythematous border area (Figure 2).

At age 18 the patient noted 2 small scalp lesions, hard and painful, that increased in number and size over the years. There was no personal or family history relevant to her condition. Her otorhinolaryngologist reported a slight visible central nasal pyramid with slight irregularities.

Histopathology showed a stratum corneum with basketweave pattern, irregular acanthosis and hyperpigmentation of basal layer, superficial, and middle dermis with dilated blood vessels, atrophic hair follicles, no alteration of sweat glands, and a mild perivascular inflammatory lymphocytic infiltrate. The subcutaneous cellular tissue contained a cluster of mature bone tissue with blood vessels and connective tissue. Bone trabeculae had osteocytes (Figure 3).

The simple lateral skull and contrast inversion radiograph showed punctiform images in the skin and subcutane- 


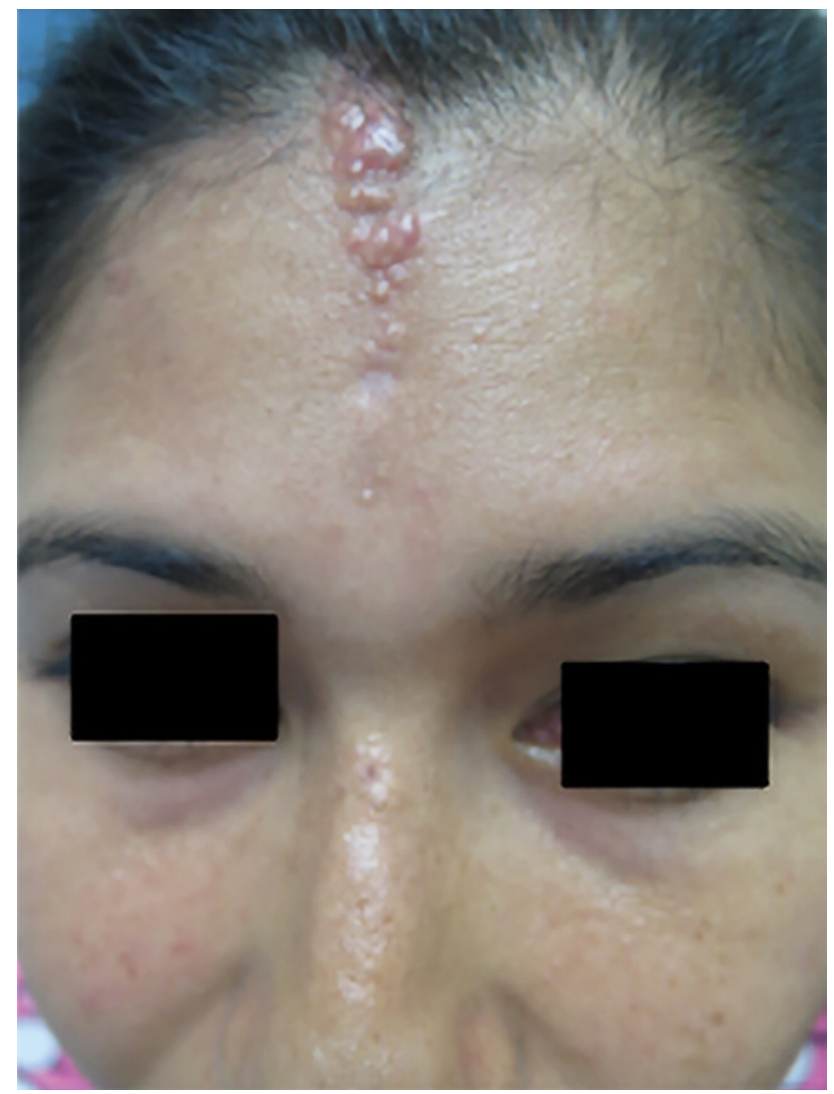

Figure 1. Clinical features: Plaque-like tumor on the patient's scalp, forehead, and nose. [Copyright: (O2019 Romero Navarrete et al.]

ous cellular tissue of the frontal region and nasal pyramid (Figure 4A,B).

Laboratory values such as thyroid and lipid profile, blood chemistry, and serum calcium and phosphorus levels were within normal ranges.

\section{Discussion}

Osteoma cutis, first described by Wilkens in 1858 , is a benign tumor of bone in the dermis or hypodermis [1]. It is classified as primary or secondary. The primary forms represent $14 \%-15 \%$ of all cutaneous ossifications and can be present in association with Albright hereditary osteodystrophy, progressive ossification, fibrodysplasia, or progressive osseous heteroplasia, as well as isolated, osteoma, generalized or multiple facial miliaria and plaques; and occasionally they present with transepidermal bone elimination. Secondary forms have a previous trauma, infection, inflammation, or neoplasia [1,2].

The term osteoma cutis in plaque was given by Worret and Burgdorf in 1978 [3]. This entity can be congenital or be present in the first year of life. It is associated with neither metabolic calcium nor phosphorus alteration, nor with previous trauma or infections. It is composed of one or more plaques of bone tissue.

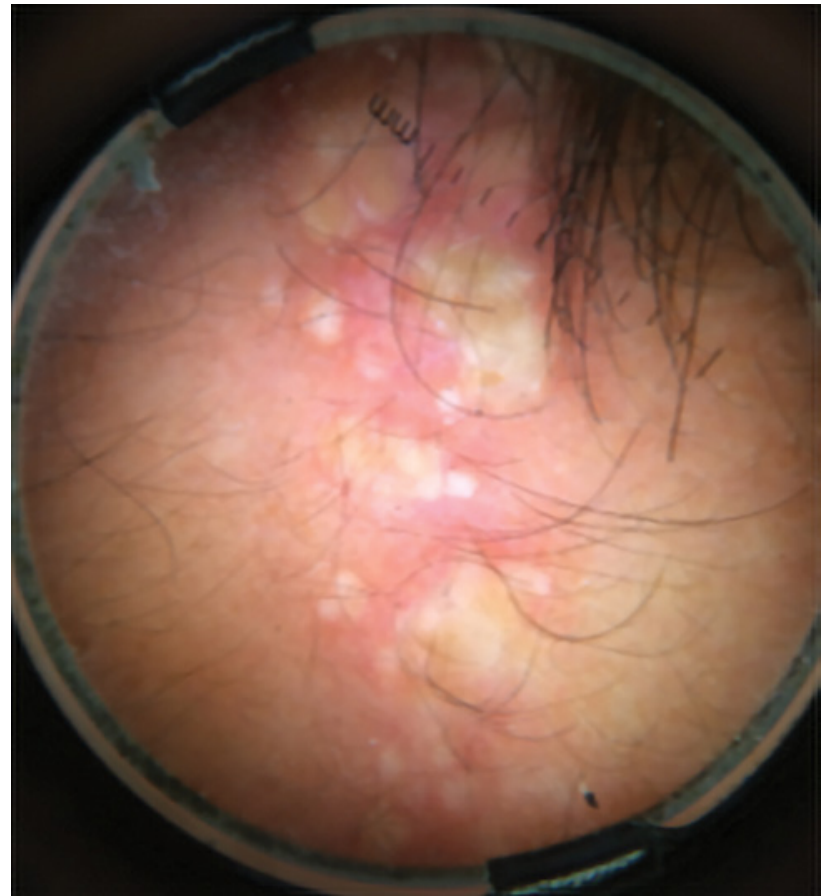

Figure 2. Dermoscopic image: Well-limited, concentric structures in linear arrangement with an erythematous and nacreous pink border. [Copyright: (C2019 Romero Navarrete et al.]

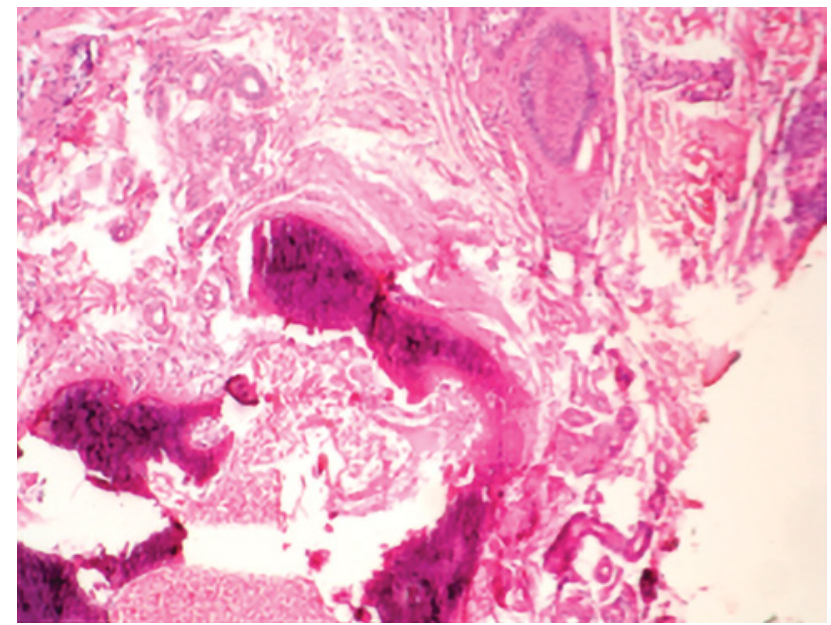

Figure 3. Histopathology: Clusters of mature bone and bone trabeculae with osteocytes, blood vessels, and connective tissue (hematoxylin and eosin, 40x). [Copyright: @2019 Romero Navarrete et al.]

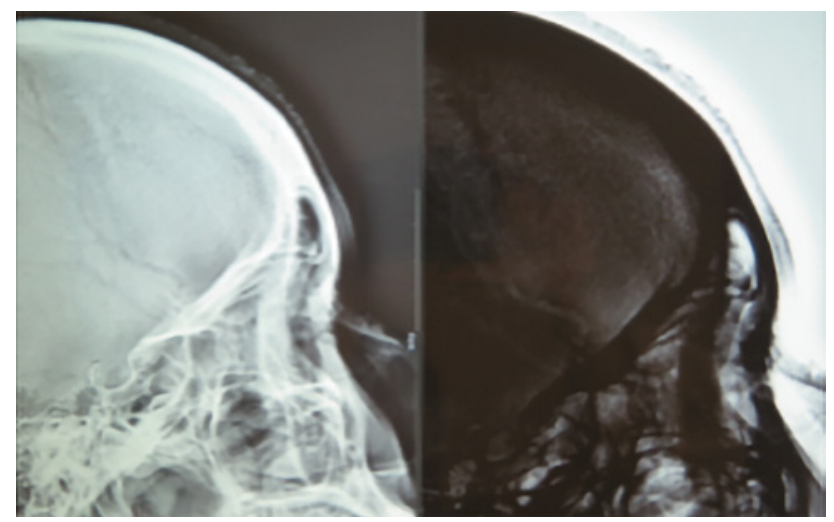

Figure 4. X-ray: Forehead and nasal pyramid with punctiform lesions in the skin and subcutaneous cellular tissue. [Copyright: (C2019 Romero Navarrete et al.] 
Table 1. Publications Describing Plaque-Like Osteoma Cutis: 1985-2017

\begin{tabular}{|c|c|c|c|c|c|c|c|c|}
\hline Author & Year & Sex & $\begin{array}{c}\text { Age at } \\
\text { Onset } \\
\text { (years) }\end{array}$ & Topography & $\begin{array}{c}\text { Histo- } \\
\text { pathology }\end{array}$ & $\begin{array}{l}\text { Dermo- } \\
\text { scopy }\end{array}$ & $\begin{array}{c}\text { Evolution } \\
\text { (years) }\end{array}$ & $\begin{array}{c}\text { Transepidermal } \\
\text { Elimination } \\
\text { of Bone }\end{array}$ \\
\hline Katz $M$ et al & 1985 & $\mathrm{~F}$ & 24 & Thorax & Yes & No & 2 & No \\
\hline Cottoni $\mathrm{F}$ et al & 1993 & $\mathrm{M}$ & 31 & Forehead & Yes & No & 20 & Yes \\
\hline Henrich DE et al & 1997 & $\mathrm{~F}$ & 69 & Scalp & Yes & No & 15 & Yes \\
\hline Fazeli P et al & 1999 & $\mathrm{~F}$ & 66 & Thigh, knee & Yes & No & 30 & Yes \\
\hline $\begin{array}{l}\text { Boschert MT } \\
\text { et al }\end{array}$ & 2000 & $\mathrm{M}$ & 77 & Hand & Yes & No & 5 & No \\
\hline Grandhe $\mathrm{N}$ et al & 2004 & $\mathrm{M}$ & 50 & Scalp & Yes & $\mathrm{No}$ & 1 & Yes \\
\hline Douri T et al & 2006 & $\mathrm{~F}$ & 25 & Scalp & Yes & No & N/A & No \\
\hline $\begin{array}{l}\text { Ayavini NAM } \\
\text { et al }\end{array}$ & 2006 & $\mathrm{~F}$ & 20 & $\begin{array}{l}\text { Forehead, } \\
\text { parietal region }\end{array}$ & Yes & No & 4 & No \\
\hline Cohen PR et al & 2007 & $\mathrm{M}$ & 48 & $\begin{array}{l}\text { Temporal } \\
\text { region }\end{array}$ & Yes & No & Childhood & No \\
\hline Haro $\mathrm{R}$ et al & 2009 & M & 35 & $\begin{array}{l}\text { Scalp, } \\
\text { forehead, } \\
\text { cheek }\end{array}$ & Yes & No & 14 & Yes \\
\hline Aneiros FJ et al & 2010 & M & 25 & Forehead & Yes & $\mathrm{No}$ & 18 months & No \\
\hline Salhi A et al & 2010 & M & 22 & Postauricular & Yes & No & 18 months & No \\
\hline Vashi $\mathrm{N}$ et al & 2011 & M & 50 & $\begin{array}{l}\text { Scalp, cheek, } \\
\text { thorax, thighs }\end{array}$ & Yes & No & 31 & No \\
\hline Wu M et al & 2011 & M & 40 & $\begin{array}{l}\text { Scalp, nose, } \\
\text { thorax, lower } \\
\text { extremities }\end{array}$ & Yes & No & 13 & No \\
\hline Talsania $\mathrm{N}$ et al & 2011 & $\mathrm{M}$ & 25 & Scalp & Yes & $\mathrm{No}$ & Birth & No \\
\hline Orme CM et al & 2014 & $\mathrm{M}$ & 53 & Scalp & Yes & $\mathrm{No}$ & Childhood & No \\
\hline Ma HJ et al & 2014 & $\mathrm{~F}$ & 25 & $\begin{array}{l}\text { Parietal region, } \\
\text { forehead }\end{array}$ & Yes & No & 5 & No \\
\hline Coutinho I et al & 2014 & $\mathrm{~F}$ & 10 & Parietal region & Yes & No & 9 & No \\
\hline $\begin{array}{l}\text { Swaroop MR } \\
\text { et al }\end{array}$ & 2016 & $\mathrm{M}$ & 28 & Scalp & Yes & No & 4 & No \\
\hline $\begin{array}{l}\text { Moreira AG } \\
\text { et al }\end{array}$ & 2017 & $\mathrm{~F}$ & 44 & $\begin{array}{l}\text { Scalp, } \\
\text { forehead }\end{array}$ & Yes & Yes & 20 & No \\
\hline $\begin{array}{l}\text { Romero } \\
\text { Navarrete M } \\
\text { et ala }\end{array}$ & 2019 & $\mathrm{~F}$ & 18 & $\begin{array}{l}\text { Scalp, } \\
\text { forehead, nose }\end{array}$ & Yes & Yes & 9 & No \\
\hline
\end{tabular}

${ }^{a}$ Our case.

Osteoma cutis is also used to name similar lesions that are acquired after the first year of life [1]. Its pathogenesis is unknown, and it has been related to the abnormal migration of osteoblast to the skin or a metaplasia of fibroblast to osteoblasts.

The case described in this report corresponds to a primary plaque osteoma cutis in an adult woman, with 9 years of evolution without reported abnormality in calcium, phosphorus, or any previous trauma or infection. Histopathology showed mature bone cluster in the subcutaneous cellular tissue.
We searched PubMed using the key words osteoma cutis, primary osteoma cutis, plaque-like osteoma cutis, acquired plate-like, plate-like osteoma cutis, and primary osteoma cutis. We found 20 publications concerning primary osteoma cutis $[1,2]$, and with our report there are 21 (Table 1).

Previous reports found $57 \%$ of osteoma cutis occurring in males and $43 \%$ in females, with an age range from 10 to 77 years, median 37.8 .

Our patient had the most frequently found topography, with clinical features similar to those of previously 
reported cases; it is the second case described with dermoscopic findings $[1,2]$.

Previously reported treatments include surgery in $40 \%$ of cases [1,2]. One patient was treated with $0.025 \%$ retinoic acid [2]. Two cases with follow-up at 6 months and 2 years reported no new lesions or recurrences $[1,2]$.

\section{Conclusions}

We report the first primary plaque-like osteoma cutis case in Mexico with histopathological correlation. This is an uncommon entity and our case is the second one that includes dermoscopic findings.

\section{References}

1. Haro R, Revelles JM, Angulo J, et al. Plaque-like osteoma cutis with transepidermal elimination. J Cutan Pathol. 2009;36(5):591-593.

2. Moreira AG, Mastrangelo MFE, Carvalho QD, Cuzzi T, Canedo de MT, Raso BP. Primary isolated osteoma cutis on the face. Dermatol Online J. 2017;23(4):1-4.

3. Worret WI, Burgdorf W. Congenital plaque-like osteoma of the skin in an infant [in German]. Hautzart. 1978;29(1):590-596. 